\title{
GEORGICA IV
}

\author{
vs. 425-529
}

425/ Ya el ardiente Sirio calcinando a los indios sedientos fulguraba en el cielo y el ígneo sol habia devorado la mitad de su curso; se marchitaban las hierbas y los rayos del sol hacian arder los cóncavos ríos, secas sus gargantas, recalentados hasta el légamo, cuando Proteo desde las ondas marchaba a su acostumbrada caverna; los húmedos pobladores

$430 /$ del vasto ponto, / brincando a su alrededor, esparcen a lo lejos su amargo rocio. Las focas, somnolientas se extienden dispersas en la playa. Proteo, como a veces el pastor en los montes, cuando ya el Véspero recoge de los prados los rebaños hacia el redil y los corderos

435 / excitan a los lobos haciéndoles oír sus balidos. / Se sienta él en el medio, sobre una roca y recuenta su grey. En cuanto se ofreció a Aristeo la oportunidad esperando apenas a que el anciano tendiera sus fatigados mienbros, gritando se abalanza y con cadenas lo prende

440/ desprevenido /. El, por su parte, sin olvidar sus ardides, adquiere todo género de portentosas formas: fuego, bestia espantosa, huidiza corriente. Pero al no lograr la fuga con sus astucias, vencido retoma su figura y así hablo al fin con voz humana: ¿"Pues quién te mandó

445/venir a mis moradas, / oh tú, el más osado de los mancebcs? ¿Qué buscas aqui??" -le dijo. Y respondió Aristeo: "Tú lo sabes, Proteo, bien lo sabes. No es posible engañarte, así que no lo finjas. Siguiendo mandatos de los dioses he venido hasta aqui buscando oráculos para mi fallida suerte". Sólo esto dijo. Ante tales palabras, por fin el adivi-

450 / no torció con violencia / sus ojos que ardian con glaucos reflejos y bramando fuertemente abrió su boca para el oráculo.

"Las iras de algún numen te acosan, expias una grave falta. El desdichado Orfeo,(1) a menos que se opongan los hados, suscita contra ti

455/ estos lamentables castigos, menores sin embargo que los merecidos / y riguroso se ensaña por la pérdida de su esposa. La joven, destinada a morir, mientras huia de tí corriendo a lo largo del rio, no vio ante sus pies en la alta hierba una enorme serpiente que habitaba la ribera.

460/ Entonces el coro de las Driadas, iguales en edad, / rebasó la cima de los montes con su clamor: lloraron las cumbres del Ródope (2), las alturas Pangeas, la marcial tierra de Reso, y los getas y el Hebro y Orithyia la ateniense. El mismo Orfeo, dando consuelo a su pena de amor con la cóncava lira, cantaba a ti, dulce esposa, a ti, a solas consi-

465/go en la desierta ribera; / a ti al nacer el dia, a ti al morir el sol. Penetró él hasta las gargantas del Ténaro (3), profundas puertas de Dite y en el bosque oscurecido por pavorosa tiniebla, llegó hasta los Manes, hasta el rey tremendo corazones éstos que no saben ablandar-

$470 /$ se ante los humanos ruegos. / Mas, conmovidas por sus acentos acudían desde los profundos abismos del Erebo las tenues sombras, los 
espectros de los que carecen ya de luz asi como en bandadas se refugian los millares de aves en las frondas cuando el Véspero o la tormenta invernal las ahuyenta de los montes: madres y esposos,

475/ cuerpos exánimes / de magnánimos héroes, niños y doncellas jóvenes puestos en la pira ante los ojos de sus padres. A su alrededor, el negro cieno, los tristes cañaverales del Cócito (4), la inhóspita laguna de

480/ tarda corriente los retiene, / y los estrecha la Estigia que nueve veces las rodea. Mas aún, atónitas se quedaron las mismas moradas, los tartáreos abismos de la Muerte, las Euménides con oscuras serpientes en sus cabellos enroscadas. Mantuvo Cérbero abiertas sus tres fauces, y cesó con el viento el girar de la rueda de Ixión. Ya Orfeo había supe-

485 / rado de regreso todos los escollos / y su recobrada Eurídice llegaba a las auras superiores siguiéndolo detrás (pues tal condición había puesto Pro sérpina), cuando súbita demencia dominó al incauto amante, perdonable ciertamente si los manes supieran perdonar. Se detuvo y olvidado ¡ay! de todo, vencido en su pasión y ya en los umbrales de la luz, se

490/ volvió a mirar a Euridice./En ese instante perdióse toda su fatiga y al quebrantarse los pactos del implacable tirano, tres veces se escuchó un fragor en los estanques del Averno(5). Y Furídice dijo: ¿¿Qué me perdió a mî, desdichada, y a ti, Orfeo? ¿Qué delirio tan grande? He

495/ aquí que nuevamente me llama hacia atrás / el cruel destino y el sueno cubre mis ojos anegados. Y ahora, adiós. Me arrastra la tenebrosa noche que me circunda mientras jay! ya no más tuya tiendo hacia ti mis palmas impotentes". Asi dijo y de pronto, como el humo mezclado a la brisa tenue, dando la espalda se desvaneció ante los ojos de

500/Orfeo /; y no vio más al que abrazando en vano las sombras, intentaba decirle tantas cosas. Ni el barquero(6) del Orco le permitió atravesar nuevamente la laguna que le cerraba el paso. ¿Qué podía él hacer? ¿Adónde se encaminaria ahora, arrebatada ya dos veces su esposa? ¿Con qué llanto conmoveria a los manes, o a cuáles númenes con

$505 /$ sus palabras? / La esposa en tanto ya yerta, bogaba en la barca de la Estigia. Cuentan que Orfeo lloró sin cesar siete meses a solas consigo bajo una elevada roca junto a la corriente del desierto Estrimón(7) y que repitió su duelo bajo las frias estrellas amansando a las fieras y

$510 /$ moviendo los bosques con su canto. / Así, Filomela (8) doliente a la sombra del álamo llora sus perdidos polluelos que el cruel labriego al acecho arrebató aún implumes del nido. Por eso llora en la noche y posada en la rama renueva su triste canto haciendo resonar los bos-

515 / ques a lo lejos con su afligido lamento. / Ningún amor, ningún otro himeneo cautivaron el ánimo de Orfeo. El solo recorría los hilos hiperbóreos, el nivoso Tánais (9) y los campos a los que nunca faltan las escarchas rifeas (10), doliéndose por su perdida Eurídice y por los vanos. favores de Dite.

520 Desdeñadas las mujeres ciconias(11) por tal homenaje de fidelidad /, en medio de los sacrificios de los dioses y de las nocturnas orgias de Baco, esparcieron por los anchurosos campos los restos del mancebo por ellas despedazado. Aún entonces, cuando el Hebro(12) tracio arrastrando la cabeza cercenada del alabastrino cuello la hacia rodar entre sus remolinos, su propia voz todavia y su yerta lengua, a Eurídi- 
525/ ce / jay! , a la desventurada Euridice llamaba, al tiempo que se le escapaba el alma, y las riberas a lo largo del rio ¡Euridice! respondian".

Tal habló Proteo y de un salto se arrojó a lo profundo del mar y allí,donde se sumergió, levantó un torbellino de espumosas olas.

María Teresita Belfiore.

\section{NOTAS}

1.- v. 455. Orfeo, cantor legendario de Tracia, hijo de Apolo o Eagro y de la musa Calíope.

2.- v. 461. El Ródope es un monte de Tracia como también el Pangeo es una cadena de montañas de esa región. Reso condujo a los tracios al sitio de Troya. Los getas habitaban la región comprendida entre los ríos Danubio y Dniéster. Orithyia, hija de.Erecteo, rey de Atenas.

3.- v. 467. El Ténaro es un promontorio de Laconia, hoy cabo Matapán. Una de sus gargantas gozaba de la fama de ser acceso a las moradas infernales.

4.- v. 479-484. Cócito, río del Tártaro.

5.- El lago Averno en Campania era considerado como una de las entradas a los infiernos.

6.-v.502. Caronte.

7.- v. 508. Rio de Tracia.

8.- Filomela en la mitología clásica es el ruiseñor.

9.- v. 517. El Tánais, actual Don, rio de la Sarmacia.

10.- Los Rifeos, cadena de montañas que para los antiguos significaban el punto más alejado hacia el norte. Actualmente se suelen ubicar en la Sarmacia antigua.

11.- v. 520. Los ciconios eran un pueblo de Tracia, habitantes de las vecindades del Hebro.

12.- v. 524. El adjetivo eagrio unido a Hebro proviene de Eagro, rey de Tracia comaderado padre de Orfeo al igual que Apolo. 